\title{
Effects of water potential on spore germination and viability of Fusarium species
}

\author{
D. Palmero Llamas • M. de Cara Gonzalez • \\ C. Iglesias Gonzalez • G. Ruíz Lopez • \\ J. C. Tello Marquina
}

\begin{abstract}
Germination of macroconidia and/or microconidia of 24 strains of Fusarium solani, F. chlamydosporum, $F$. culmorum, $F$. equiseti, $F$. verticillioides, $F$. sambucinum, $F$. oxysporum and $F$. proliferatum isolated from fluvial channels and sea beds of the south-eastern coast of Spain, and three control strains ( $F$. oxysporum isolated from affected cultures) was studied in distilled water in response to a range of water potentials adjusted with $\mathrm{NaCl}$. $(0$, $-13.79,-41.79,-70.37,-99.56$ and -144.54 bars). The viability $(\mathrm{UFC} / \mathrm{ml})$ of suspensions was also tested in three time periods $(0,24$ and $48 \mathrm{~h})$. Conidia always germinated in distilled water. The pattern of conidial germination observed of $F$. verticilloides, $F$. oxysporum, $F$. proliferatum, F. chlamydosporum and F. culmorum was similar. A great diminution of spore germination was found in -13.79 bars solutions. Spore germination percentage for $F$. solani isolates was maximal at $48 \mathrm{~h}$ and -13.79 bars with $21.33 \%$ spore germination, $16 \%$ higher than germination in distilled water. $F$. equiseti shows the maximum germination percentage in -144.54 bars solution in $24 \mathrm{~h}$ time with $12.36 \%$ germination. This results did not agree with those obtained in the viability test were maximum germination was found in distilled water. The viability analysis showed the great capacity of $F$. verticilloides strains to form viable colonies, even in such extreme conditions as -144.54 bars after $24 \mathrm{~h}$
\end{abstract}

$F$. proliferatum colony formation was prevented in the range of -70.37 bars. These results show the clear affectation of water potential to conidia germination of Fusaria. The ability of certain species of Fusarium to develop a saprophytic life in the salt water of the Mediterranean Sea could be certain. Successful germination, even under high salty media conditions, suggests that Fusarium spp. could have a competitive advantage over other soil fungi in crops irrigated with saline water. In the specific case of $F$. solani, water potential of -13.79 bars affected germination positively. It could indicate that $F$. solani has an special physiological mechanism of survival in low water potential environments.

\section{Introduction}

Spore germination of Fusarium genus is a quick process that can take place in short periods of $4-7 \mathrm{~h}$ in the majority of cases, macroconidia show lower germination speed in axenic cultures [14].

Conidial germination is characterized by the formation of one or two germ tubes [14], some authors observe swelling or increase in size during or previous to germination [19, 30]. Different authors had indicated that Fusarium culmorum macroconida contains an outer mucilaginous sheath [30], or carbohydrates of $F$. solani or $F$. avenaceum, that could act as specific receptors for plant lectins [18].

Endogenous substrates of conidia are sufficient to support germination, Fusarium conidia are known to have a high lipid content which allows it. Energetic requirements that favour conidial germination have been broadly studied, indicating that there are absolute requirements for exoge- 
nous organic carbon substrates (sugars, alcohols, organic acids, amino acids) and nitrogen sources [3, 9, 13-15, 19]. Regarding the influence of the chemical environment on germination, provision of a balanced inorganic salt medium provides a more suitable environment for germination [14].

Ragazzy and Vecchio [21] indicated that, salinities of 10 $\mathrm{dS} / \mathrm{m}$, increase both germination and length of clamidospore germination tube in $F$. oxysporum f. sp. vasinfectum, with extreme decrease with salinities of $15 \mathrm{ds} / \mathrm{m}$, authors suggested that cotton fields irrigated with saline water could increase infection in cotton.

Percentage of spore germination for six isolates of $F$. graminearum, $F$. culmorum and $F$. avenaceum, including conidia, clamydospores and ascospores was uniformly maximal at all water potentials between -1 and -20 bars, and prevented in the range of -60 and -80 bars. [25]. In $F$. moniliforme, germination percentage decreased from $80.3 \%$ germination in media with no amended $\mathrm{NaCl}$ until $0 \%$ germination observed in $15 \% \mathrm{NaCl}$ medium [1].

Research dedicated to the Fusarium genus in aquatic habitats is not frequent, perhaps because it is considered a ground (soil-borne) fungus. The presence of Fusarium spp. has been reported in marshy waters. $F$. merismoides was mentioned by Booth [5] in dirty stagnant water and mud. Articles on fungi in fluvial water mention the presence of Fusarium as a decomposer of leaves and branches from trees fallen into the channel $[2,8,22,31] . F$. culmorum and $F$. aquaeductum $[23,24]$ and Fusarium sp. [7] have been sporadically isolated from river channels in Southeast Spain, which were considered saprophytes.

Tello and Lacasa [26] studied the presence of Fusarium sp. in uncultivated land, finding a high proportion of $F$. solani and $F$. oxysporum. These authors questioned the relationship between the isolated species and those that produced diseases in crops surrounding the uncultivated ground sampled, especially in the case of $F$. oxysporum. In carnation crops in the sampled area, $F$. oxysporum f.sp. dianthi causes a limiting mycosis. Two important mycoses were found in tomato crops, one caused by $F$. oxysporum f.sp. lycopersici (Fusarium wilt) and another caused by $F$. oxysporum f.sp. radicislycopersici (Fusarium crown and root rot).

The presence of Fusarium sp. in beach sand and marine sea beds on the Mediterranean coast of Spain has been broadly studied $[20,27,28]$. The study was justified to search for possible sources of pathogen inoculate for several vascular fusariosis in the sand-covered crops of Almeria (South-eastern Spain). Sand-covered cultivation is a production technique for 20,000 ha of greenhouse crops, consisting of covering the original soil with a thin layer (2$3 \mathrm{~cm}$ ) of fresh manure and then adding a $10-15 \mathrm{~cm}$ thick layer of sand. This technique has been used for more than 50 years, permitting utilization of saline water $(2,000-$ $5,000 \mathrm{mmhos}$ of conductivity) in susceptible crops.
This present study shows the analysis to know the effect of water potential on spore germination of seven different Fusarium sp. isolated from these habitats.

\section{Materials and methods}

Isolated used in germination tests

A total of 21 strains of $F$. solani, $F$. chlamydosporum, $F$. culmorum, $F$. equiseti, $F$. verticillioides, $F$. oxysporum and $F$. proliferatum isolated from fluvial channels and sea beds of the south-eastern coast of Spain and three control strains: $F$. oxysporum f. sp. lycopersici race $0 F$. oxysporum f. sp. radicis cucumerinum and $F$. oxysporum $\mathrm{f}$. sp. melonis race 1 (all isolated from affected cultures and coded as "AC") were analyzed.

The origin and code of the isolates of Fusarium tested can be seen on Table 1. All strains used in this study are stored in the University of Almería (Plant Prod. Dept.) and in the Polytecnic University of Madrid (E.U.I.T. Agrícola) culture collections.

\section{Conidial germination}

Germination was tested in distilled water in response to a range of osmotic potentials adjusted with $\mathrm{NaCl}$ (Table 2).

Each of the isolates was sub-cultured from selective medium Komada [17] to $20 \mathrm{ml} \mathrm{PDA}-\mathrm{KCl}(6 \mathrm{~g} / \mathrm{l})$ medium [29]. Twelve cultures per isolate were incubated under ultra violet light (12.000 lux) for 10 days. After that, Petri dishes were washed twice with $5 \mathrm{ml}$ of each salt solution in distilled water and the control without salt addition.

Germination percentages were calculated as mean germination values measured in hematocytometer (Malassez $0.00050 \mathrm{~mm}^{3}$ ) at 0,24 and $48 \mathrm{~h}$ in 12 replications per isolate for each osmotic pressure.

Viability test

The viability of suspensions was also tested in three time periods $(0,24$ and $48 \mathrm{~h})$ by placking $0.25 \mu \mathrm{l}$ washing solution (five replicates per osmotic pressure and isolate) in $15 \mathrm{ml}$ PDA media. Results were calculated as mean number of colony former unit (CFU) per ml followed by standard deviation.

\section{Statistical analysis of data}

The statistical treatment of data was carried out using STATGRAPHICS Plus 5.1 statistical package software (StatPoint, Inc. 2325 Dulles Corner Boulevard, Suite 500 Herndon, Virginia 20171). Analysis of variance were car- 
Table 1 Origin of Fusarium isolates used in tests ( $D$ : depth)

\begin{tabular}{|c|c|c|c|c|}
\hline \multirow{3}{*}{$\begin{array}{l}\text { Analysis code } \\
\text { FUS } 2\end{array}$} & \multirow{3}{*}{$\begin{array}{l}\text { Fusarium spp. } \\
\text { F. verticillioides (Sacc.) Nirenberg }\end{array}$} & \multicolumn{3}{|l|}{ Location } \\
\hline & & \multirow{2}{*}{$\begin{array}{l}\text { Sample depth } \\
\text { Mouth of Andarax River bed } D=1.5 \mathrm{~m}\end{array}$} & \multicolumn{2}{|c|}{ UTM coordinates } \\
\hline & & & 551238 & 4074229 \\
\hline FUS 7 & F. oxysporum Schlechtendahl emend. Snyder \& Hansen & Mouth of Andarax River bed $D=0.1 \mathrm{~m}$ & 551169 & 4074231 \\
\hline FUS 13 & F. solani (Martius) Saccardo & Mouth of Andarax River bed $D=0.1 \mathrm{~m}$ & 551169 & 4074231 \\
\hline FUS 18 & F. oxysporum Schlechtendahl emend. Snyder \& Hansen & Mouth of Albuñol River bed $D=4.5 \mathrm{~m}$ & 485881 & 4066493 \\
\hline FUS 21 & F. verticillioides (Sacc.) Nirenberg & Mouth of Albuñol River bed $D=4.5 \mathrm{~m}$ & 485881 & 4066493 \\
\hline FUS 22 & F. verticillioides (Sacc.) Nirenberg & Mouth of Albuñol River bed $D=4.5 \mathrm{~m}$ & 485881 & 4066493 \\
\hline FUS 28 & F. oxysporum Schlechtendahl emend. Snyder \& Hansen & Mouth of Albuñol River bed $D=1.5 \mathrm{~m}$ & 485772 & 4066598 \\
\hline FUS 31 & F. solani (Martius) Saccardo & Mouth of Albuñol River bed $D=1.5 \mathrm{~m}$ & 485772 & 4066598 \\
\hline FUS 111 & F. equiseti (Corda) Sace. & Albuñol River Highway N342 & 551041 & 4074596 \\
\hline FUS. 52 & F. equiseti (Corda) Sacc. & Sea bed at $6 \mathrm{~m}$ in depth & 550786 & 4073856 \\
\hline FUS 60 & F. solani (Martius) Saccardo & Sea bed at $6 \mathrm{~m}$ in depth & 550844 & 4073833 \\
\hline FUS 101 & $F$. proliferatum var. minus & Andarax River & 545284 & 4090359 \\
\hline FUS 102 & $F$. proliferatum var. minus & Andarax River & 545284 & 4090359 \\
\hline FUS 106 & F. proliferatum (Matsushima) Nirenberg & Andarax River & 545284 & 4090359 \\
\hline FUS 115 & F. culmorum (W.G. Smith) Sacc. & Andarax River & 545284 & 4090359 \\
\hline FUS 118 & F. culmorum (W.G. Smith) Sacc. & Andarax River & 549372 & 4086274 \\
\hline FUS 119 & F. sambucinum Fuckel sensu lato & Andarax River & 549372 & 4086274 \\
\hline FUS 121 & F. culmorum (W.G. Smith) Sacc. & Andarax River & 549372 & 4086274 \\
\hline FUS 130 & F. chlamydosporum Wollenweber \& Reinking & Andarax River & 574058 & 4090020 \\
\hline FUS 132 & F. chlamydosporum Wollenweber \& Reinking & Andarax River & 574058 & 4090020 \\
\hline FUS 133 & F. chlamydosporum Wollenweber \& Reinking & Andarax River & 574058 & 4090020 \\
\hline
\end{tabular}

Table 2 Relations between the osmotic potential of the medium $(\psi)$ and the concentrations of $\mathrm{KCl}$ and $\mathrm{NaCl}$

\begin{tabular}{lcc}
\hline$\psi$ (bars) & \multicolumn{2}{l}{ Product amount $(\mathrm{g} / \mathrm{l}$ of PDA) } \\
\cline { 2 - 3 } & $\mathrm{NaCl}^{\mathrm{a}}$ & $\mathrm{KCl}^{\mathrm{a}}$ \\
\hline$-1.50^{\mathrm{b}}$ & 0.0 & 0.0 \\
-13.79 & 17.6 & 22.2 \\
-41.79 & 52.0 & 68.8 \\
-70.37 & 84.8 & 112.0 \\
-99.56 & 115.2 & 152.8 \\
-144.54 & 156.6 & 212.5 \\
\hline
\end{tabular}

a Jakobsen et al. [16]

b Cook [10]

ried out for the germination rates so that numbers with the same letter do not differ significantly.

\section{Results and discussion}

Germination test

Fusarium conidia showed germination in tests in aqueous medium. Results show how conidial germination, for the
Table 3 Variance analysis of germination depending on incubation period

\begin{tabular}{lcrrrr}
\hline Variable & $\begin{array}{l}\text { Sums of } \\
\text { squares }\end{array}$ & DF & $\begin{array}{l}\text { Mean } \\
\text { squares }\end{array}$ & $F$ & $P$ value \\
\hline Among groups & 805.902 & 2 & 402.951 & 7.47 & 0.0006 \\
Intra groups & 72675.2 & 1347 & 52.953 & & \\
Total (Corr.) & 73481.1 & 1349 & & & \\
\hline
\end{tabular}

$F D$ freedom degrees

$P$ : signification of mean difference with previous value

genus as a whole, increases with germination period up to an average of $2.81 \%$ of germination $48 \mathrm{~h}$ later.

The percentage of germinated spores was significantly different among incubation periods (Table 3). Conidial germination increases with time from an average rate of $0.939 \pm 5.54$ at $0 \mathrm{~h}$ incubation to $2.093 \pm 7.12$ and $2.815 \pm$ 8.96 at 24 and $48 \mathrm{~h}$, respectively. Significant differences between the different incubation periods studied were noted.

The conidial germination pattern of Fusarium genus, broken down for each studied osmotic pressure is showed in Fig. 1, the figure shows how germination in distilled water increases with incubation period.

Germination in distilled water increases with incubation period up to a maximum of $48 \mathrm{~h}(10.67 \%)$. Less conidial 
Fig. 1 Fusarium germination $(\%)$ in response to a range of water potentials

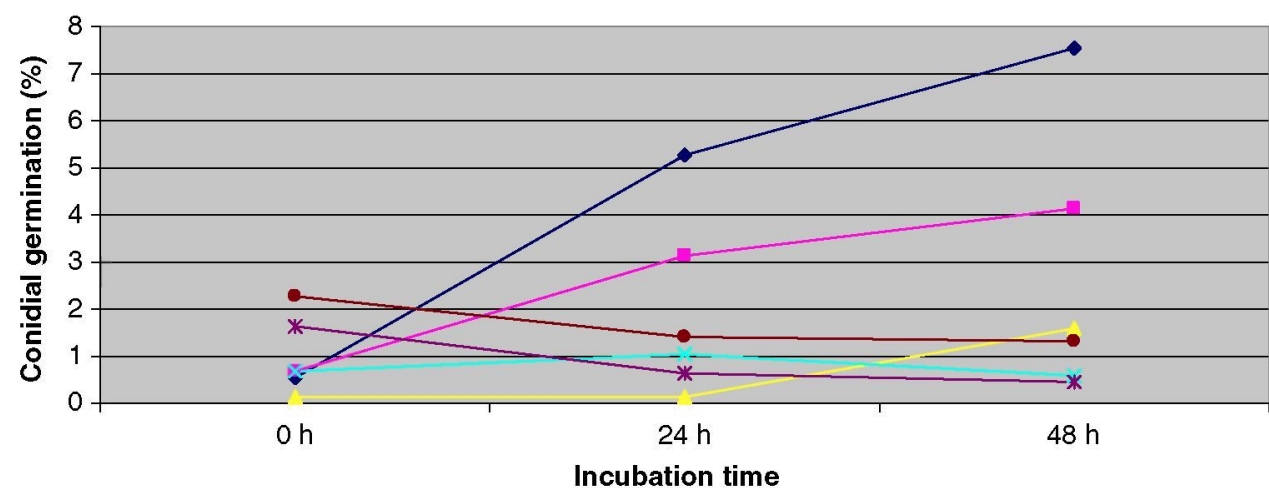

$\begin{gathered}\text { Osmotic pressure } \\ \text { (bars) }\end{gathered} \longrightarrow 0 \rightarrow-13,79-41,79 \rightarrow-70,37 \rightarrow-99,56 \multimap-144,54$ germination was observed in solutions with osmotic potential of -13.79 bars, although conidia kept on showing germination, which increased in parallel with incubation period up to $5.75 \%, 48 \mathrm{~h}$ later.

These results are coincident in part with those obtained by Gilbert [11] for ascospores germination of Giberella zeae (anamorph $F$. graminearum), germination rates were highest at $90 \% \mathrm{RH}$ at 15 and $20^{\circ} \mathrm{C}$.

Beyer $[3,4]$ demonstrated that relative humidity was a key factor in germination of $G$. zeae ascospores. At RH over $84 \%$ and $20{ }^{\circ} \mathrm{C}$ almost $100 \%$ of the freshly discharged ascospores germinated. Successful germination, even under extreme conditions, suggests that ascospores are sufficiently robust to constitute a source of inoculum under most environmental conditions.

In the same way as in the germination of ascospores and, although the germination rates of asexual spores are not so high, germination raised over time. The percentages of conidial germination observed in this study may indicate that the asexual spores are not the main form of survival in aqueous media. Although it allows their survival in aqueous environments.

The rest of the saline solutions tested, with lower osmotic potential, did not show effects in germination, which in any case exceeded $2.4 \%$ of germination during tested incubation periods, but it is necessary to underline that they showed germination in all the osmotic pressures tested.

The germination results were analysed distinguishing the three tested incubation periods and Fusarium sp.

\section{Analysis at $0 \mathrm{~h}$ with every isolate}

Conidia did not show practically germination in distilled water, with an average germination of $0.939521 \pm 5.54$, mostly because of $F$. equiseti, as it will be shown distinguishing results for each of the tested species.

$F$. equiseti was the only species that was able to germinate at $0 \mathrm{~h}$ time (Table 4). These results could indicate both higher germination rate of conidia of this species in question, opposite with the rest of the studied species, and lower requirement of exogenous sources of energy to unleash germination. However, it is surprising that $0 \mathrm{~h}$ of incubation produced germination. A speculation could be the fact that those conidia were germinated in Petri dish of origin and they were swept out during the washing.

\section{Analysis at $24 \mathrm{~h}$ with every isolate}

Results verify that there are significant differences between averages of germination (Table 5). There are differences

Table 4 Conidial germination percentages in each tested species at $0 \mathrm{~h}$

\begin{tabular}{lcccccc}
\hline & Treatment 0 & Treatment 1 & Treatment 2 & Treatment 3 & Treatment 4 & Treatment 5 \\
\hline F. chlamydosporum & $0.0 \pm 0.0 \mathrm{a}$ & $0.0 \pm 0.0 \mathrm{a}$ & $0.0 \pm 0.0 \mathrm{a}$ & $0.0 \pm 0.0 \mathrm{a}$ & $0.0 \pm 0.0 \mathrm{a}$ & $0.0 \pm 0.0 \mathrm{a}$ \\
F. culmorum & $0.0 \pm 0.0 \mathrm{a}$ & $0.0 \pm 0.0 \mathrm{a}$ & $0.0 \pm 0.0 \mathrm{a}$ & $0.0 \pm 0.0 \mathrm{a}$ & $0.0 \pm 0.0 \mathrm{a}$ & $0.129 \pm 0.38 \mathrm{a}$ \\
F. equiseti & $4.629 \pm 9.41 \mathrm{~b}$ & $6.075 \pm 9.44 \mathrm{~b}$ & $1.234 \pm 3.70 \mathrm{~b}$ & $6.076 \pm 9.32 \mathrm{~b}$ & $14.629 \pm 22.10 \mathrm{~b}$ & $13.308 \pm 21.43 \mathrm{~b}$ \\
F. oxysporum & $0.0 \pm 0.0 \mathrm{a}$ & $0.0 \pm 0.0 \mathrm{a}$ & $0.0 \pm 0.0 \mathrm{a}$ & $0.0 \pm 0.0 \mathrm{a}$ & $0.0 \pm 0.0 \mathrm{a}$ & $0.01 \pm 0.04 \mathrm{a}$ \\
m & $0.0 \pm 0.0 \mathrm{a}$ & $0.0 \pm 0.0 \mathrm{a}$ & $0.0 \pm 0.0 \mathrm{a}$ & $0.0 \pm 0.0 \mathrm{a}$ & $0.0 \pm 0.0 \mathrm{a}$ & $0.0 \pm 0.0 \mathrm{a}$ \\
F. sambucinum & $0.0 \pm 0.0 \mathrm{a}$ & $0.0 \pm 0.0 \mathrm{a}$ & $0.0 \pm 0.0 \mathrm{a}$ & $0.0 \pm 0.0 \mathrm{a}$ & $0.0 \pm 0.0 \mathrm{a}$ & $0.0 \pm 0.0 \mathrm{a}$ \\
F. solani & $0.0 \pm 0.0 \mathrm{a}$ & $0.0 \pm 0.0 \mathrm{a}$ & $0.0 \pm 0.0 \mathrm{a}$ & $0.0 \pm 0.0 \mathrm{a}$ & $0.0 \pm 0.0 \mathrm{a}$ & $0.0 \pm 0.0 \mathrm{a}$ \\
F. verticillioides & $0.155 \pm 0.12 \mathrm{a}$ & $0.187 \pm 0.13 \mathrm{a}$ & $0.112 \pm 0.01 \mathrm{a}$ & $0.092 \pm 0.07 \mathrm{a}$ & $0.106 \pm 0.08 \mathrm{a}$ & $0.108 \pm 0.09 \mathrm{a}$ \\
AC & $0.0 \pm 0.0 \mathrm{a}$ & $0.0 \pm 0.0 \mathrm{a}$ & $0.0 \pm 0.0 \mathrm{a}$ & $0.101 \pm 0.30 \mathrm{a}$ & $0.0 \pm 0.0 \mathrm{a}$ & $0.0 \pm 0.0 \mathrm{a}$ \\
\hline
\end{tabular}


between treatment 0 and treatment 1 as well as between both and the others (Table 6). Germination rates for each species at $24 \mathrm{~h}$ incubation are shown in Table 7.

The pattern of conidial germination observed in $F$. culmorum, $F$. oxysporum, $F$. proliferatum, $F$. sambucinum and $F$. verticilloides was similar (Table 7). Germination was uniformly maximal in distilled water, drastically lower in aqueous solutions with osmotic potentials between -13.79 and -41.79 bars and prevented in the range of -70.37 and -144.54 bars. The three of the isolates used as control samples behave as an isolate of $F$. oxysporum isolated from aquatic habitat.

Germination pattern in $F$. chlamydosporum was similar except for the observed drop in germination percentages at -13.79 and -41.79 bars that was progressive. It was not observed a drastic decrease of the germination percentage in saline aqueous media.

Table 5 Descriptives of germination of Fusarium depending on osmotic pressure

\begin{tabular}{lrrrrr}
\hline Variable & $\begin{array}{l}\text { Sums of } \\
\text { squares }\end{array}$ & DF & $\begin{array}{l}\text { Mean } \\
\text { squares }\end{array}$ & $F$ & $P$ value \\
\hline Among groups & 1626.9 & 5 & 325.379 & 6.82 & 0.0 \\
Intra groups & 21182.5 & 444 & 47.708 & & \\
Total (Corr.) & 22809.4 & 449 & & & \\
\hline
\end{tabular}

$F D$ freedom degrees

$P$ : signification of mean difference with previous value

Table 6 Variance analysis of Fusarium conidial germination depending on osmotic pressure at $24 \mathrm{~h}$ incubation

\begin{tabular}{lll}
\hline Treatment & Frequency & $\begin{array}{l}\text { Average } \pm \text { standard } \\
\text { deviation }\end{array}$ \\
\hline 0 & 75 & $5.694 \pm 10.65 \mathrm{a}$ \\
1 & 75 & $3.392 \pm 8.69 \mathrm{~b}$ \\
2 & 75 & $0.148 \pm 0.32 \mathrm{c}$ \\
3 & 75 & $1.151 \pm 5.43 \mathrm{c}$ \\
4 & 75 & $0.673 \pm 2.60 \mathrm{c}$ \\
5 & 75 & $1.401 \pm 7.78 \mathrm{c}$ \\
\hline
\end{tabular}

On the other side, conidial germination of $F$. solani and $F$. equiseti was positively affected due to the osmotic pressure of aqueous medium. Conidial germination percentages of $F$. solani were the highest in solutions with osmotic pressures of -13.79 bars with $14.55 \%$ of germinated sample, $12 \%$ higher than germination observed in distilled water. $F$. equiseti shows the highest germination percentage $(12.36 \%)$ in solutions with osmotic potentials of -144.54 bars.

\section{Analysis at 48 h time with every isolate}

There are differences between averages of germination at 48 h of incubation (Table 8 ).

Table 9 shows that there are differences between treatment 0 and treatment 1 as well as between both and the others.

The pattern of conidial germination observed at $24 \mathrm{~h}$ in $F$. culmorum, $F$. oxysporum, $F$, proliferatum, $F$. sambucinum and $F$. verticilloides remains at $48 \mathrm{~h}$ (Table 10).

Glenn [12] studied the variation in spore germination of $F$. verticillioides, the author state two different phenotypes. In general, germination tubes immediately penetrated into agar, but other isolates formed germ tubes that grew along the surface of agar. The invasive germination was the predominant phenotype and was more virulent than other strains tested.

The observed differences in the germination percentages of different species could be explained by the genetic variability within the strains. Further analysis should determine the possible correlation between the conidial germination and virulence of the isolates.

Germination was uniformly the maximum in distilled water. In case of $F$. chlamydosporum, the observed decrease in germination percentages at -13.79 and -41.79 bars is still progressive.

The two species that were positively affected by osmotic pressure of aqueous medium, keep on showing that influence. Just like at $24 \mathrm{~h}$, conidial germination percentages of $F$. solani were the highest at $48 \mathrm{~h}$ in treatment $1(-13.79$ bars of osmotic pressure) with $21.33 \%$ if germinated conidia, $16 \%$ higher than observed germination in distilled water. Percent-

Table 7 Results of variance analysis of conidial germination for each studied species at $24 \mathrm{~h}$ of incubation

\begin{tabular}{lllllll}
\hline & Treatment 0 & Treatment 1 & Treatment 2 & Treatment 3 & Treatment 4 & Treatment 5 \\
\hline F. chlamydosporum & $7.246 \pm 10.83 \mathrm{ab}$ & $2.871 \pm 4.36 \mathrm{ab}$ & $0.055 \pm 0.09 \mathrm{a}$ & $0.129 \pm 0.38 \mathrm{a}$ & $1.084 \pm 1.72 \mathrm{a}$ & $2.2 \mathrm{E}-16 \pm 0.0 \mathrm{a}$ \\
F. culmorum & $11.985 \pm 9.12 \mathrm{bc}$ & $0.338 \pm 0.61 \mathrm{a}$ & $0.0 \pm 0.0 \mathrm{a}$ & $0.175 \pm 0.27 \mathrm{a}$ & $2.2 \mathrm{E}-16 \pm 0.0 \mathrm{a}$ & $4.4 \mathrm{E}-16 \pm 0.0 \mathrm{a}$ \\
F. equiseti & $2.681 \pm 3.88 \mathrm{a}$ & $8.562 \pm 9.78 \mathrm{bc}$ & $0.460 \pm 0.66 \mathrm{~b}$ & $9.046 \pm 0.06 \mathrm{~b}$ & $4.408 \pm 6.39 \mathrm{~b}$ & $12.369 \pm 20.25 \mathrm{~b}$ \\
F. oxysporum & $0.831 \pm 1.19 \mathrm{a}$ & $0.101 \pm 0.09 \mathrm{a}$ & $0.081 \pm 0.07 \mathrm{a}$ & $0.051 \pm 0.0 \mathrm{a}$ & $0.0 \pm 0.0 \mathrm{a}$ & $0.029 \pm 0.08 \mathrm{a}$ \\
F. proliferatum & $4.335 \pm 4.75 \mathrm{ab}$ & $0.140 \pm 0.21 \mathrm{a}$ & $0.0 \pm 0.0 \mathrm{a}$ & $0.0 \pm 0.0 \mathrm{a}$ & $0.0 \pm 0.0 \mathrm{a}$ & $0.0 \pm 0.0 \mathrm{a}$ \\
F. sambucinum & $0.229 \pm 0.39 \mathrm{ab}$ & $8.4 \mathrm{E}-15 \pm 0.0 \mathrm{ab}$ & $-2.2 \mathrm{E}-16 \pm 0.0 \mathrm{a}$ & $-1.5 \mathrm{E}-15 \pm 0.0 \mathrm{a}$ & $-6.6 \mathrm{E}-16 \pm 0.0 \mathrm{a}$ & $-4.4 \mathrm{E}-16 \pm 0.0 \mathrm{a}$ \\
F. solani & $1.875 \pm 3.70 \mathrm{a}$ & $14.555 \pm 18.88 \mathrm{c}$ & $0.465 \pm 0.40 \mathrm{~b}$ & $0.110 \pm 0.14 \mathrm{a}$ & $-1.1 \mathrm{E}-16 \pm 0.0 \mathrm{a}$ & $-2.2 \mathrm{E}-16 \pm 0.0 \mathrm{a}$ \\
F. verticillioides & $1.631 \pm 2.33 \mathrm{a}$ & $0.335 \pm 0.33 \mathrm{a}$ & $0.074 \pm 0.02 \mathrm{a}$ & $0.075 \pm 0.04 \mathrm{a}$ & $0.107 \pm 0.13 \mathrm{a}$ & $0.105 \pm 0.14 \mathrm{a}$ \\
AC & $16.791 \pm 22.81 \mathrm{c}$ & $1.361 \pm 1.71 \mathrm{a}$ & $0.098 \pm 0.15 \mathrm{a}$ & $0.005 \pm 0.01 \mathrm{a}$ & $0.011 \pm 0.02 \mathrm{a}$ & $0.009 \pm 0.02 \mathrm{a}$ \\
\hline
\end{tabular}


Table 8 Descriptives of germination of Fusarium depending on osmotic pressure

\begin{tabular}{lcrcrl}
\hline Variable & $\begin{array}{l}\text { Sums of } \\
\text { squares }\end{array}$ & DF & $\begin{array}{l}\text { Mean } \\
\text { squares }\end{array}$ & $F$ & $P$ value \\
\hline Among groups & 3319.28 & 5 & 663.857 & 9.00 & 0.0 \\
Intra groups & 32734.7 & 444 & 73.7267 & & \\
Total (Corr.) & 36054.0 & 449 & & & \\
\hline
\end{tabular}

$F D$ freedom degrees

$P$ : signification of mean difference with previous value

Table 9 Variance analysis of Fusarium conidial germination depending on osmotic pressure at $48 \mathrm{~h}$ incubation

\begin{tabular}{lll}
\hline Treatment & Frequency & $\begin{array}{l}\text { Average } \pm \text { standard } \\
\text { deviation }\end{array}$ \\
\hline 0 & 75 & $8.128 \pm 15.96 \mathrm{a}$ \\
1 & 75 & $4.486 \pm 9.38 \mathrm{~b}$ \\
2 & 75 & $1.721 \pm 5.13 \mathrm{c}$ \\
3 & 75 & $0.644 \pm 2.65 \mathrm{c}$ \\
4 & 75 & $0.503 \pm 2.38 \mathrm{c}$ \\
5 & 75 & $1.407 \pm 7.75 \mathrm{c}$ \\
\hline
\end{tabular}

age observed in treatment $2(-41.79$ bars $)$ is lower than treatment 1 , but $3.6 \%$ higher than the one in distilled water.

$F$. equiseti keeps on showing the highest germination percentage $(10.76 \%)$ in solutions with osmotic potentials of -144.54 .

Viability test

The results of the viability tests are shown in Fig. 2. The histogram shows the high viability of the Fusarium studied with a mean of all treatments tested of $260273.832 \mathrm{CFU} / \mathrm{ml}$.

Following incubation periods with different saline concentration, it could be observed how viability remains undermined by the aqueous medium, with a marked reduction of CFU. The effect of the first saline concentration tested ( -13.79 bars) is not different to the control treatment in distilled water and it is lower than the rest of osmotic pressures tested.

The harmful effect observed in conidial germination with osmotic pressures below -41.79 bars confirms the results of the viability studies, which showed a drastic drop in the number of UFC from the first saline concentration tested (Fig. 2).

The favorable effect of salinity observed in the germination of $F$. solani is not so clear in relation to viability while there are no significant differences, after $48 \mathrm{~h}$ incubation,

Table 10 Results of variance analysis of conidial germination for each studied species at $48 \mathrm{~h}$ of incubation

\begin{tabular}{lcccccc}
\hline & Treatment 0 & Treatment 1 & Treatment 2 & Treatment 3 & Treatment 4 & Treatment 5 \\
\hline F. chlamydosporum & $2.939 \pm 4.64 \mathrm{a}$ & $2.663 \pm 4.03 \mathrm{a}$ & $2.315 \pm 3.02 \mathrm{a}$ & $0.002 \pm 0.01 \mathrm{a}$ & $0.5 \pm 0.99 \mathrm{a}$ & $0.925 \pm 2.77 \mathrm{a}$ \\
F. culmorum & $17.961 \pm 18.81 \mathrm{~b}$ & $0.830 \pm 1.16 \mathrm{a}$ & $0.118 \pm 0.23 \mathrm{a}$ & $0.223 \pm 0.35 \mathrm{a}$ & $5.5 \mathrm{E}-17 \pm 0.0 \mathrm{a}$ & $4.4 \mathrm{E}-16 \pm 0.0 \mathrm{a}$ \\
F. equiseti & $8.292 \pm 7.25 \mathrm{a}$ & $10.042 \pm 11.71 \mathrm{~b}$ & $3.392 \pm 6.29 \mathrm{a}$ & $4.486 \pm 6.76 \mathrm{~b}$ & $3.289 \pm 6.41 \mathrm{~b}$ & $10.761 \pm 20.87 \mathrm{~b}$ \\
F. oxysporum & $1.214 \pm 1.77 \mathrm{a}$ & $0.163 \pm 0.19 \mathrm{a}$ & $0.138 \pm 0.15 \mathrm{a}$ & $0.247 \pm 0.36 \mathrm{a}$ & $0.011 \pm 0.01 \mathrm{a}$ & $0.0 \pm 0.0 \mathrm{a}$ \\
F. proliferatum & $5.024 \pm 7.00 \mathrm{a}$ & $0.171 \pm 0.27 \mathrm{a}$ & $0.037 \pm 0.05 \mathrm{a}$ & $0.001 \pm 0.0 \mathrm{a}$ & $1.1 \mathrm{E}-16 \pm 0.0 \mathrm{a}$ & $2.2 \mathrm{E}-16 \pm 0.0 \mathrm{a}$ \\
F. sambucinum & $0.229 \pm 0.39 \mathrm{a}$ & $-1.1 \mathrm{E}-14 \pm 0.0 \mathrm{a}$ & $-2.8 \mathrm{E}-15 \pm 0.0 \mathrm{a}$ & $-1.2 \mathrm{E}-15 \pm 0.0 \mathrm{a}$ & $-1.1 \mathrm{E}-15 \pm 0.0 \mathrm{a}$ & $-2.4 \mathrm{E}-15 \pm 0.0 \mathrm{a}$ \\
F. solani & $4.832 \pm 4.16 \mathrm{a}$ & $21.333 \pm 14.26 \mathrm{c}$ & $8.026 \pm 11.43 \mathrm{~b}$ & $0.192 \pm 0.29 \mathrm{a}$ & $0.005 \pm 0.01 \mathrm{a}$ & $-2.2 \mathrm{E}-16 \pm 0.0 \mathrm{a}$ \\
F. verticillioides & $4.413 \pm 5.78 \mathrm{a}$ & $0.388 \pm 0.49 \mathrm{a}$ & $0.282 \pm 0.35 \mathrm{a}$ & $0.214 \pm 0.26 \mathrm{a}$ & $0.393 \pm 0.56 \mathrm{a}$ & $0.043 \pm 0.04 \mathrm{a}$ \\
AC & $22.985 \pm 36.39 \mathrm{~b}$ & $1.796 \pm 2.72 \mathrm{a}$ & $0.037 \pm 0.05 \mathrm{a}$ & $0.0009 \pm 0.0 \mathrm{a}$ & $-6.3 \mathrm{E}-16 \pm 0.0 \mathrm{a}$ & $-1.3 \mathrm{E}-15 \pm 0.0 \mathrm{a}$ \\
\hline
\end{tabular}

Fig. 2 Viability of Fusarium from river and sea beds, responding to the osmotic potential, given as colony formation units per millilitre ( $\mathrm{CFU} \mathrm{m}{ }^{-1}$ )

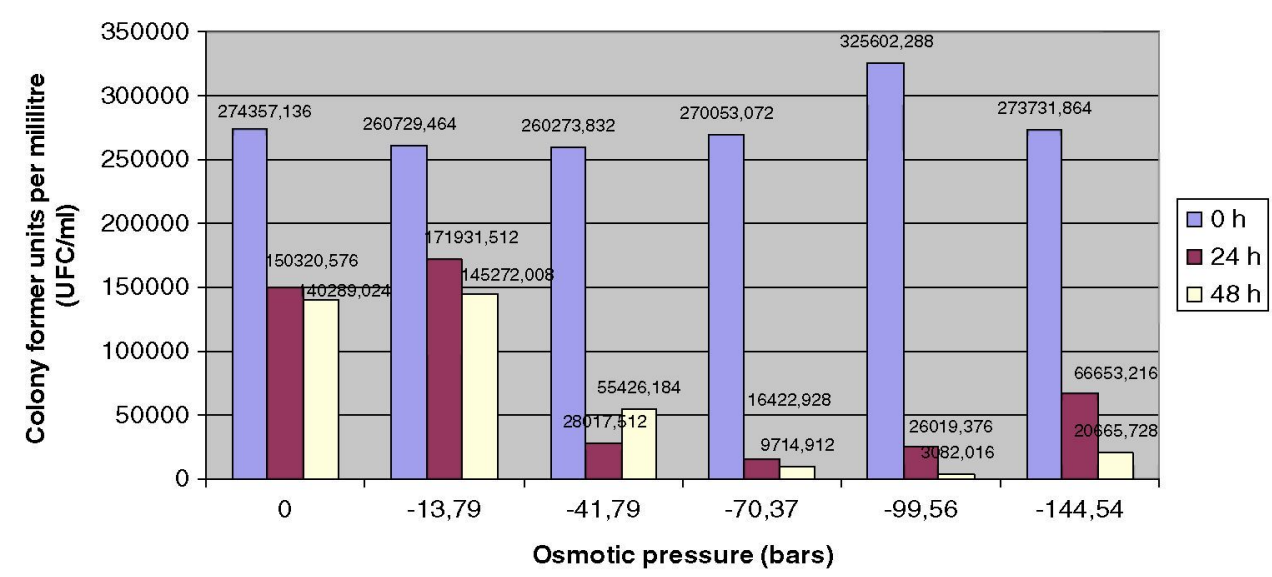


among the treatment with distilled water (84486.6 UFC) and osmotic pressure of -13.79 ( 82806 UFC) and -41.79 bars(71560 UFC).. The adverse effect of salt is visible from -70.37 bars pressure and keeps on increasing with incubation time and lower osmotic potentials.

In the case of $F$. equiseti, the results show that the aquatic environment clearly favors the viability, from $1,09,000 \mathrm{CFU} / \mathrm{ml}$ at $0 \mathrm{~h}$ to $10,58,000 \mathrm{CFU} / \mathrm{ml}$ at $48 \mathrm{~h}$.

The first saline concentration tested $(\mathrm{ce}=24.8 \mathrm{mS} / \mathrm{ml})$ tolerates the viability of $F$. equiseti, which reaches $1,32,000 \mathrm{CFU} / \mathrm{ml}$ at $48 \mathrm{~h}$ of incubation. Higher salinities seriously affect Fusarium and prevent the viability of the isolated studied.

We must underline the differential behaviour showed by $\mathrm{T} 2$ isolate against the rest of $F$. oxysporum studied. Just like it happened with $F$. solani, this isolate shows more viability at $48 \mathrm{~h}$ at -13.79 bars $(818485.8 \mathrm{CFU})$ than in distilled water (560955.93 CFU). Finally, in the particular case of $F$. sambucinum viability is completely null at 24 and $48 \mathrm{~h}$, then it could be said that it does not present any survival capacity in aqueous media and it could explain, partly, the low presence of the specie in the original sampling, in which is based this study.

Electric conductivity of Sea water at the mouth of the River Andarax ranges between 50 and $54.40 \mathrm{dS} / \mathrm{m}$. Treatment 1 and 2 represent respectively approximately electric conductivities of 24.8 and $60.5 \mathrm{dS} / \mathrm{m}$, therefore, the experimental results indicate that the conditions present at seabed are more favorable to germination of these fungi than distilled water, with no salt added to the medium. The ability of certain species of Fusarium to develop a saprophytic life in the salt water of the Mediterranean Sea could be certain.

Results show how conidial germination in aqueous medium increased with germination period. Some of the Fusarium sp. studied are potential mycotoxin producers. Mycotoxins as deoxinivalenol or zearalenone were detected in Swiss rivers [6], these and other mycotoxins exibit high solubility. The ecotoxicological effects of the presence of mycotoxins in surface waters remain to be elucidated.

Successful germination, even under high salty media conditions, suggests that Fusarium sp. could have a possible competitive advantage over other soil fungi in crops irrigated with saline water. Practical implications as the possible proliferation of Fusaria in farmland or glasshouse crops irrigated with saline water should also be attempted.

\section{References}

1. Abou-Zeid AM (2000) Growth zearalenone production and some metabolic activities of Fusarium moniliforme under salt stress. Acta microbial Pol 49(3-4):225-235

2. Bärlocher F, Kendrix B (1974) Dynamics of the fungal populations on leaves in a stream. J Ecol 62:761-791
3. Beyer M, Verraat JA (2005) Germination of Giberella zeae ascospores as affected by age of spores after discharge and environmental factors. Eur J Plant Pathol 111:381-389

4. Beyer M, Verraat JA, Ragab WSM (2005) Effect of relative humidity on germination of ascospores and macroconidia of Gibberella zeae and deoxynivalenol production. Int J Food Microbiol 98:233-240

5. Booth C (1971) The genus Fusarium. Commonwealth Mycolological Institute, Kew, p 237

6. Bucheli TD, Wettstein FE, Hartmann N, Erbs M, Vogelgsang S, Forrer HR, Schwarzenbach RP (2008) Fusarium mycotoxins: Overlooked aquatic micropollutans. J Agric Food Chem 56:10291034

7. Casas JJ, Descals E (1997) Aquatic hyphomycetes from Mediterranean streams contrasting in chemistry and riparian canopy. $\mathrm{Li}-$ mnetica 13:45-55

8. Charmier AC, Dixon PA, Archer SA (1984) The spatial distribution of fungi on decomposing alder leaves in a freshwater stream. Oecologia (Berl) 64:92-103

9. Cochrane VW, Cochrane JC, Vogel JM, Coles RS (1963) Spore germination and carbon metabolism in Fusarium solani. IV. Metabolism of ethanol and acetate. J Bacteriaol 86:312-319

10. Cook RJ (1973) Influence of low plant and soil water potentials on diseases caused by soilborne fungi. Phytopathology 63:451-458

11. Gilbert J, Woods SM, Kromer U (2008) Germination of ascospores of Gibberella zeae after exposure to various levels of relative humidity and temperature. Phytopathology 98:504-508

12. Glenn AE (2006) Natural variation of ascospore and conidial germination by Fusarium verticillioides and other Fusarium species. Mycol Res 110:211-219

13. Griffin GJ (1969) Fusarium oxysporum and Aspergillus flavus spore germination in the rizosphere of peanut. Phytopathology 59:1214-1218

14. Griffin GJ (1970) Carbon and nitrogen requirements for macroconidial germination of Fusarium solani: dependence on conidial density. Can J Microbiol 16:733-740

15. Griffin GJ, Pass T (1969) Behaviour of Fusarium roseum "sambucinum" under carbon starvation conditions in relation to survival in soil. Can J Microbiol 15:117-126

16. Jakobsen M, Filtenborg O, Bramsnaes F (1972) Germination and outgrowth of the bacterial spore in the presence of different isolates. Lebensm Wiss u Technol vol 5(5):159-162

17. Komada H (1975) Development of a selective medium for quantitative isolation of Fusarium oxysporum from natural soil. Rev Plant Prot Res 8:114-125

18. Kleinschusterand SJ, Baker R (1974) Lectins detectable differences in carbohydrate-containing surface moieties of macroconidia of Fusarium roseum "avenaceum" and Fusarium solani. Phytopathology 64:394-399

19. Marchant R, White MF (1966) Spore swelling and germination in Fusarium culmorum. J Gem Microbiol 42:237-244

20. Nuñez FJ, Palmero D, Iglesias C, De Cara M, Sinobas J, Tello JC (2006) Biogeografía de especies de Fusarium en el litoral mediterráneo de España. Bol San Veg Plagas 32:137-149

21. Ragazzy A, Vecchio V (1992) Behaviour of chlamidospore of Fusarium oxysporum $\mathrm{f}$. sp. vasinfectum in substrates containing sodium chloride. Phytopath Medit 31:85-87

22. Révay A, Gönczöl J (1990) Longitudinal distribution and colonization patterns of wood-inhabiting fungi in a mountain stream in Hungary. Nova Hedwigia 51:505-520

23. Roldan A, Honrubia M (1990) Catalogo provisional de los deuteromicetos acuáticos de la provincia de Alicante. Bol Soc Micol Madrid 14:21-42

24. Roldan A, Puig MA, Honrubia M (1989) Comunidades fúngicas asociadas a sustratos leñosos en un río mediterráneo. Ann Limnol 25:191-195 
25. Sung J, Cook RJ (1971) Effect of water potential on reproduction and spore germiantion by Fusarium roseum "graminearum" "culorum" and "avenaceum". Phytopath Vol 71(5):499-503

26. Tello JC, Lacasa A (1990) Fusarium oxysporum en los cultivos intensivos del litoral mediterráneo de España. Fases parasitaria (Fusariosis vasculares del tomate y del clavel) y no parasitaria. Bol San Veg Plagas 19:1-190

27. Tello JC, Lacasa A, Rodriguez MC (1990) Presence of some Fusarium species on Spanish beaches. Proceedings of the 8th congress of the Mediterranean phytopathological union. Agadir, Morocco, pp 137-138
28. Tello JC, Rodriguez MC, Lacasa A (1992) Importancia de Fusarium en las arenas de playas de España. ITEA 88:77-94

29. Tello JC, Vares F, Lacasa A (1991) Análisis de muestras. In: Manual de laboratorio: diagnostico de hongos, bacterias y nematodos fitopatógenos. M.A.P.A. Madrid, pp 39-48

30. Wilson EM (1960) Physiology of an isolate of Fusarium oxysporum f.sp. cubense. Phytopathology 50:607-612

31. Wylloughby LG, Archer JF (1973) The fungal spore in a freshwater stream and its colonization pattern on wood. Freshwater Biol $3: 219-239$ 